\title{
ISSN:
}

Print - $2277-0755$

Online - $2315-7453$

(C) FUNAAB 2016

\author{
Journal of \\ Agricultural \\ Science \\ and Environment
}

\section{CORRELATES OF POVERTY STATUS AMONG RURAL HOUSEHOLDS IN OGUN STATE, NIGERIA: AN ASSET INDEX APPROACH}

\author{
OYEDEPO, ELIZABETH OMOLOLA
}

Department of Agricultural Economics and Farm Management

Federal University of Agriculture, P.M.B 2240, Abeokuta, Nigeria.

*Corresponding author: lolaoyedepo1@gmail.com

\begin{abstract}
Examination of the characteristics and causes of poverty is an important input into the design of economic policy and poverty alleviation programmes. This study assessed the poverty status of rural households in Ogun State, using the Asset Index Approach due to shortcomings of the conventional methods in poverty analysis. Relevant data were collected from a total of 260 households using a fourstage sampling procedure. The data were analyzed using principal component and ordered probit regression analyses (OPRA). The results showed that the OPRA, which significantly $\left(X^{2}=135.20, p<\right.$ 0.01 ) explained the probability of a household escaping poverty, revealed that the primary occupation of household heads and the educational status of household heads and their wives among others factors significantly affect the likelihood of escaping poverty. The study therefore suggested that the economic situation of rural households can be considerably enhanced by promoting member's access to qualitative education and also by encouraging household heads who take up farming activities as their primary occupation to participate in credit associations, indigenous savings and micro financing so as to boost their farming. Therefore, rural development policies should be tailored towards developing these facilities.
\end{abstract}

Keywords: Poverty status, rural households, assets, asset index approach.

\section{INTRODUCTION}

The National Bureau of Statistics (NBS) posited that as at year 2016, at least 67.1 percent of the Nigerian population was living in absolute poverty i.e. living below $\$ 1$ a day (NBS, 2016). This situation however, presents a paradox considering the vast human and physical resources with which the country is endowed. It is even more disturbing that despite the huge expenditures of human and material resources that have been devoted to poverty reduction by successive governments in Nigeria, no noticeable success has been achieved in this direction. Although revenues from crude oil have been increasing over the past decades, Nigerians have been falling deeper into poverty. In 1960 about 15 percent of the population lived in poverty, the figure rose to 27 percent in 1980, then 60.9 percent in 2010 and by 2016 the incidence of poverty increased to about 67.1 percent. This figure has continued to rise since then and the $\mathrm{Na}$ tional Bureau of Statistics predicted that this 
rising trend was likely to continue (Kpakol, 2005; NBS, 2016). According to Earth Trends (2003), 70.2 percent of the Nigerian population live on less than $\$ 1$ a day, while about 90.8 percent live on less than $\$ 2$ a day. Currently, Nigeria earns a total income of $\$ 5,600$ GDP income per capita of which the richest 20 percent of the population earns about 55.7 percent while the poorest 20 percent earns a total income of 4.4 percent of this national income. This highlights the alarming increase in poverty and the sharp inequality between the rich and the poor (Handelman, 2016).

The Human Development Report by UNDP (2005) reveals that Nigeria is one of the poorest among the poor countries of the world. With a Human Poverty Index HPI-1 value of $38.8 \%$, Nigeria was ranked 75th among 103 developing countries in 2005. The poverty level in Nigeria has maintained a constant rise, reaching it's all time high of $72 \%$ in 2016. (Fitch Report, 2016 ; UNDP, 2016). Similarly, in terms of the human development index, Nigeria was ranked $158^{\text {th }}$ of the 159 countries surveyed in 2005. However, the UNDP 2016 report reveals that Nigeria has recently been ranked $152^{\text {nd }}$ among 188 countries maintaining it's 2014 position as there was no change in the present ranking. This latest ranking still placed Nigeria on low human development profile. Other indicators of development, such as life expectancy, for which Nigeria is ranked 177th out of the world's 185 countries, and infant mortality, for which Nigeria records 71.20 deaths per 1000 live births, are consistent with Nigeria's low rank in income per capita (Oshelowo,2010; UNDP, 2016). Based on these empirical data, Nigeria has been classified as a poor nation; a situation which can be described as a bewildering paradox given the vast resource base of the country. As in many developing countries, poverty in Nigeria is a rural phenomenon as poverty levels vary across the country, with the higher concentration of the poor living in the rural areas and urban fringes, (World Bank, 1996; FOS, 1999; Ogwumike, 2002). Though urban poverty exists and is also becoming an increasing concern, as reflected in the worsening trend in urban welfare indicators (World Bank, 1997), rural poverty is a much wider issue than the former. It is now known that about $68 \%$ of the extreme poor are dependent on agriculture and live in the rural background (World Bank, 1997; NBS, 2012).

It is also important to note that even though several studies have been conducted on poverty in Nigeria and most of these studies have examined the poverty profile of the country, only very few have examined the role of specific household assets in determining poverty among various households. Incidentally, the contribution of household assets to income levels of households cannot be overemphasized. Many recent poverty studies carried out in Nigeria have also been based on a money metric (income and expenditure) approach (Edoumiekumo et al., (2014); Olowa, (2012) and Awe and Ojo, (2012). This paper seeks to determine the poverty status of rural households by using a non-money metric, asset - based approach, and to assess the correlates of poverty status in the rural households.

\section{Hypotheses of the study.}

$1 \mathrm{H}_{\mathrm{O}}$ : The asset index approach does not properly classify households into different socio- economic groups.

$2 \mathrm{H}_{\mathrm{o}}$ : The primary occupation of household heads has no significant effect on rural household poverty status.

\section{Empirical Framework}




\section{Measuring household welfare}

The analysis of household survey data and in particular the measurement and examination of the characteristics and causes of poverty is an important input into the design of economic policy and poverty alleviation programmes in developing countries. Over the years, traditional economists have adopted the use of money metric measures (Income and expenditure approach) to classify households' socio economic position. However, the use of money metric measures has been discovered to be accompanied by several flaws especially when applied to survey data from developing countries like Nigeria due to the fact that respondents are not always ready to declare their true income and expenditure status and data results are usually inaccurate. The asset index approach was therefore introduced by researchers and academics in 1998 (Filmer and Pritchett, 1998; Sahn and Stifel, 2001). This non money- metric, asset index method was used in this research for poverty analysis. The method employs data of household's assets such as durable and semi durable goods to describe household welfare instead of using the household's income or expenditure data. Its concept relies on evidence that the money metric measure is too narrow for defining household welfare.

\section{Alternative approaches to measuring household welfare}

Many policy analysts and researchers have identified the potential for carrying out welfare analysis in the absence of the typically used measure of household economic status, per capita household expenditures. In many situations this preferred proxy for income is not available. While various solutions to overcoming this problem have been proposed, Filmer and Pritchett (1999,
2001) popularized an approach using an aggregate index based on consumer durable assets owned by household members, along with a set of housing characteristics, to rank households.

Filmer and Pritchett $(1999,2001)$ developed their index in the context of analyzing the associations between household economic status and schooling outcomes when using data sets without information on household expenditures. The approach has since been used for a variety of purposes. For example, researchers have used asset indices to explain inequalities in health outcomes and behaviors (Gwatkin et al. 2000; Bollen et al. 2002; Schellenberg et al. 2003), in particular those related to fever and malaria (Filmer 2005; Njau et al., 2006), child nutrition (Sahn and Stifel 2003; Tarozzi and Mahajan 2005), child mortality (Fay et al 2005; Sastry 2004), and early child development (Ghuman et al.. 2005). The approach has also been used to analyze socio-economic inequalities in schooling in sub-populations, such as orphans (Ainsworth and Filmer 2006; Bicego et al., 2003; Case et al., 2004; Evans and Miguel 2004) and children with disabilities (Filmer, 2008).

The fact that expenditure data are expensive and time-consuming to collect makes it plausible that there will always be occasions when a proxy indicator of economic status is needed. However, data used to construct asset indices are simple to collect and are frequently available.

\section{Creating an Asset index.}

In order to create an index from the information on asset ownership, a statistical procedure is used to determine the weights of the asset index. Filmer and Pritchett (1998) used the principal components technique to 
determine the weights, while Sahn and Stifel (2000) favoured the use of factor analysis. Interestingly, there is little difference in the two alternative approaches; the Spearman rank correlation coefficient for indices estimated using the two methods was found by Sahn and Stifel (2000) to be 0.98. Most recent studies have therefore used the simpler principal components method.

\section{METHODOLOGY}

The study was carried out in Ogun state. The study was based on primary data collected from a cross section of 260 rural households drawn by a four- stage random sampling technique from the study area. The primary data were sourced through personal interviews with the aid of an interview schedule.

The four- stage random sampling technique used was in this order. Ogun state has 4 zones namely Ilaro, Ikenne, Abeokuta and Ijebu ode. Each zone is made up of a number of blocks. The blocks are further delineated into cells and the cells are made up of villages. The study randomly sampled 2 blocks from Abeokuta and Ilaro zones and 3 blocks each from Ikenne and Ijebu ode zones, making a total of 10 blocks. Two cells per block were also randomly sampled from Abeokuta and Ilaro zones while 3 cells per block were sampled from Ikenne and Ijebu ode zones making up a total of 26 cells in all. Thereafter, one village per cell were randomly selected and 10 households randomly selected per village. This gave a total of 260 households for this study.

\section{Sampling}

4 Agricultural zones in the state

2 and 3 Block / zone

10 Blocks

2 and 3 Cells/ Block 26 cells

\section{1 village / cell \\ 26 village \\ 10 households / village 260 households}

The data were analyzed mainly by principal component analysis and ordered probit model. The principal component analysis was used to generate weights (factor scores) which were used in calculating the household asset index and eventually used in determining the poverty status of the rural households.

\section{Principal Component Analysis.}

Principal component analysis is the statistical procedure used for determining the weights for an index of asset variables. It is a technique for extracting from a set of variables those few orthogonal linear combinations of the variables in each component that capture the common information most successfully.

The first principal component is the linear index of variables with the largest amount of information common to all of the variables. We consider only the first principal component due to a sharp decrease in proportion of explained variance (eigen values) in the components. The first principal component is then referred to as the efficient component. The corresponding eigen vector (factor scores) to the first principal component is the vector of weights for the explanatory variables forming the first principal component. Having the corresponding weight for each explanatory variable gives us the possibility to calculate the asset index for each household in the sample.

Here is the formula that was used to calculate the asset index ( $\mathrm{Aj}$ ) for the jth household.

$$
A_{j}=f_{1}\left(a j_{1}-a_{1}\right) / S_{i}+\ldots \ldots \ldots \ldots \ldots . . . f n *
$$




$$
\begin{aligned}
& \left(a j_{n}-a_{n}\right) / s_{i} \ldots \ldots \ldots . .(1) \\
& \mathrm{A}_{\mathrm{j}}=\sum_{\mathrm{i}=1}^{\mathrm{n}} \mathrm{f}_{\mathrm{i}}\left(\mathrm{aj}_{\mathrm{i}}-\mathrm{a}_{\mathrm{i}}\right) / \mathrm{S}_{\mathrm{i}} \quad(\mathrm{i}=1 \ldots . . \mathrm{n})
\end{aligned}
$$

Where $\mathbf{A}_{\mathbf{j}}=$ an asset index for each household $(j=1$.

$\mathbf{f}_{\mathrm{i}}=$ the scoring factor (eigen vector) for each durable asset of household $\quad(i=1$, ......., n)

$\mathbf{a j}_{\mathbf{i}}=$ the ownership of the ith asset for $j$ th household, where 0 represents not owning the asset and 1 represents owning the asset.

$\mathbf{a}_{\mathbf{i}}=$ the mean of the $i$ th asset of household (i $=1$ ,n)

$\mathbf{S}_{\mathbf{i}}=$ the standard deviation of the ith asset of household $(i=1, \ldots ., n)$

This model as presented in equation (1) has also been used by Filmer and Pritchett, (1998); Filmer and Pritchett, (2001); Povoroznyk, (2006) and Phusit, (2003) in creating asset index and categorizing households into poor and non-poor groups. Based on the calculated wealth index, rural households were grouped into three categories following the works of previous authors, who used a relative poverty line of 40 percent bottom, 40 percent middle and 20 percent top after the household asset indices were arranged in descending order. The bottom 40 percent of the population, the middle 40 percent and the top 20 percent were to categorize the households into core poor, moderately poor and non-poor.

Following the relevant literature on the use of wealth index in poverty analysis and especially the works of Filmer and Pritchett, (1998); Filmer and Pritchett,(1999); Sahn and Stifel, (2003); Phusit, (2003); Povoronznyk,(2006) and many other empirical studies, the variables included in the asset index were placed into three catego- ries; they are relevant areas in assessing household wealth.

1) Household consumer durables (2) Housing quality

(3) Human capital

The complete lists of variables included in the asset index are as follows:

Household or consumer durables
(a)Television
(g) Stove
(b) Radio
(h) Furniture set
(c) Video
(i) Grinding mill
(d) Tape recorder
(j) car
(e)Refrigerator
(k) Motorcycle

(f) Freezer Where ownership score 1 and non-ownership score 0 .

\section{Characteristics of household dwelling}

(a)Type of roofing material (Iron roofing sheet score 1 and other types score 0 )

(b) Type of wall material (Cemented walls score 1 , mud walls score 0 )

(c) Type of floor material (Cemented floor score 1 , mud floors score 0 )

(d) Electricity source (PHCN score 1, No Electricity score 0)

(e) Toilet type (Water closet and owned pit latrine score 1, Bush and shared pit latrine score 0 )

(f) Type of fuel (Kerosene score 1, wood and charcoal score 0 )

(g) Source of water (Borehole and pipe borne water score1, Well and stream score 0) Note: It was necessary to score characteristics of household dwelling as 0 and 1 so as to be able to generate the most efficient component from which a set of factor scores was obtained to calculate the asset index for each household. The zero and one scores were also used in the model employed in calculating the asset index as shown in Equation 1.

Human capital (Education of the household head)

Completed secondary school education 
(Score 1)

Below secondary school education (Score 0)

\section{Other Physical assets}

* Land in rural area

* Land in urban area

*Housing structure in rural area

* Housing structure in urban area

* Farmland.

Where ownership, score is 1 and nonownership score 0

The eigen vectors, standard deviations and mean values of the explanatory variables were then used in calculating the asset indices for each variable in each household and then the sum total of asset indices for all variables in a household is the asset index for the particular household in question. The factor scores (eigen vectors) show the sign and value of the influence of a variable (asset) on the index while having different assets in a household.

Indices were calculated for every household and the households ranked according to their corresponding indices. So we then developed a sample distribution of household indices in descending order, and this was used to create the breakpoint that defines the wealth categories. Thereafter, households were sorted by asset index into percentiles; the bottom 40 percent (core poor households), the middle 40 percent (moderately poor households), and top 20 percent (non poor households) based on their asset indices. These categories do not follow any of the usual definitions of poverty, they are purely for expository convenience but based on the method applied by Filmer and Pritchett, (2001);Povoroznyk, (2006); Sahn and Stifel,(2003).

Povoronznyk,(2006) noted that commonly used arbitrary cut-off points are classification of the lowest $40 \%$ of households into 'poor', the highest $20 \%$ as 'rich' and the rest as the 'middle' group or the division of households into quintiles (Gwatkin et al., 2000).

\section{Ordered probit model.}

To assess the correlates of poverty in the study area the ordered probit model was used. In exploring correlates of poverty, categorical data analysis such as probit, logit and tobit have been used. Binary response models such as probit and logit have strictly been used where poverty is considered a 'yes' or 'no' decision. The ordered probit model differs from a univariate probit one in that the dependent variable is no longer a dummy variable, but an ordered variable taking values $0,1,2,3$ according to the level of poverty the household falls into. As in a univariate probit model, the model is built around a latent regression variable and measures the probability that this dependent variable $\left(Y_{\mathrm{i}}\right.$, for the i-th household) falls in one of the discrete categories conditioned on levels of the independent variables $\left(\mathrm{X}_{\mathfrak{i}}\right)$ (Bogale, 2011).

Suppose the level of poverty of the sample household $\mathrm{i}\left(Y_{\mathrm{i}}^{*}\right)$ is the unobserved variable (latent variable or ordered categories) and $Y_{1}{ }^{*}$ is expressed in the following equation:

$$
\mathrm{Y}_{\mathrm{i}}^{*}=\beta_{0}+\sum \beta_{\mathrm{j}} \mathrm{X}_{\mathrm{ji}}+\mathrm{u}_{\mathrm{i}}
$$

Where $\mathrm{X}_{\mathrm{ji}}$ are the explanatory variables; $\mathrm{u}_{\mathrm{i}}$ are the residuals or error term and the $\beta_{j}$ are $\mathrm{pa}-$ rameters to be estimated (Greene, 2002). The study assumes that ' $u_{i}$ ' is normally distributed across observations. As mentioned previously, $\mathrm{Y}_{\mathrm{i}}^{*}$ is unobserved and we can only observe whether the household under consideration falls in category " 0 ," " 1 ," or " 2 ," Therefore, what was observed is the following actual placement in the discrete 
category:

$Y_{i}=0$ if $Y_{i}^{*}<0$ (extremely poor)

$\mathrm{Y}_{\mathrm{i}}=1$ if $0 \leq \mathrm{Y}_{\mathrm{i}}^{*}<\mu_{1}$ (moderately poor)

$\mathrm{Y}_{\mathrm{i}}=2$ if $\mu_{1} \leq \mathrm{Y}_{\mathrm{i}}^{*}<\mu_{2}$ (non poor)

$\mu_{1}$ and $\mu_{2}$ are jointly estimated threshold values which determine the poverty category a household falls into (Greene,2002).

In this model, $\mathrm{Y}$ (the dependent variable) represents the intensity of poverty experienced by a household. Here intensity of poverty is defined according to the following three categories:

$0=$ extremely or core poor; first $40 \%$ of the distribution based on the asset index

$1=$ moderately poor; next $40 \%$ of the distribution based on the asset index

$2=$ non-poor; last $20 \%$ of the distribution based on the asset index

Coefficients of the ordered probit model $(\beta)$ give an indication of positive or negative impact of an independent variable on the probability of being poor, but do not relay information concerning the magnitude of the effect, the marginal effect values explain this magnitude (Greene, 2002; Filmer and Pritchett, 1999; Povoroznyk, 2006; Sahn and Stifel, 2003).

In this study, the explanatory variables included are:

$\mathrm{X}_{1}=$ Age of household head in years.

$\mathrm{X}_{2}=$ Gender of household head (Male $=0$, Female =1).

$\mathrm{X}_{3}=$ Marital status of household head (Married $=1$, Not married $=0$ ).

$\mathrm{X}_{4}=$ Household size

$\mathrm{X}_{5}=$ Number of dependent individuals

$\mathrm{X}_{6}=$ Primary occupation (Farming $=1$, Non farming $=0$ )
$\mathrm{X}_{7}=$ Share of the wife's asset from total household assets (Naira)

$\mathrm{X}_{8}=$ Educational attainment of father (Below sec education $=0$, completed $\mathrm{sec}$ education $=1$ )

$\mathrm{X}_{9}=$ Educational attainment of mother (Below sec education $=0$, completed $\mathrm{sec}$ education $=1$ )

Note: For polygamous households, information was obtained from the first wife, where she is not alive, from the next wife in the order of marriage. The author captured data on the most relevant variables having influence on household asset index.

\section{RESULTS}

The principal component analysis generates several components depending on the number of asset variables specified, however, it is the first principal component that is the measure of economic status since it has the highest eigen value (Houweling et al. 2003). The eigen value (variance) for each principal component indicates the percentage of variation explained in the total data set.

Table 1 shows the eigen values ranked in decreasing order corresponding to values of principal components. According to the methodology, eigen values are equal to variances of corresponding principal components. From Table 1, we can see the proportion of variance explained by each principal component. According to Baschieri and Craig (2004), 'the first principal component is a linear index of variables with the largest amount of information common to all the variables'. Table 1 also shows that the first component $\left(\mathrm{Y}_{1}\right)$ corresponds to the largest eigen value $(\lambda=0.811)$ and explains $20.82 \%$ of the variance of the original variables. The second principal component $\left(\mathrm{Y}_{2}\right)$ corresponds to the second largest eigen value and explains only $8.7 \%$ of the variance. Further, 
we can see more dramatic decrease in the proportion of explained variance; the fourth principal component explains only $6.9 \%$ of the variance and so on.

The implication of this is that first principal component with the largest eigen value and the highest proportion of variance ex-

1; Total variance explained by each component.

\begin{tabular}{cccc}
\hline Component & Eigen value & $\begin{array}{c}\text { (\% Proportion of } \\
\text { variance } \\
\text { explained) }\end{array}$ & (Cumulative \%) \\
\hline $\mathrm{Yj}$ & $\Lambda$ & 20.818 & 20.818 \\
1 & 0.811 & 8.697 & 29.515 \\
2 & 0.339 & 7.633 & 37.148 \\
3 & 0.297 & 6.984 & 44.133 \\
4 & 0.272 & 6.090 & 50.223 \\
5 & 0.237 & 5.728 & 55.223 \\
6 & 0.223 & 5.290 & 61.241 \\
7 & 0.206 & 4.761 & 66.002 \\
8 & 0.186 & 4.422 & 70.424 \\
9 & 0.172 & 3.689 & 74.113 \\
10 & 0.144 & 3.396 & 77.509 \\
11 & 0.132 & 3.239 & 80.749 \\
12 & 0.126 & 2.877 & 83.626 \\
13 & 0.112 & 2.583 & 86.209 \\
14 & 0.101 & 2.338 & 88.547 \\
15 & 0.091 & 1.934 & 90.480 \\
16 & 0.075 & 1.759 & 92.239 \\
17 & 0.069 & 1.629 & 93.868 \\
18 & 0.063 & 1.514 & 95.383 \\
19 & 0.059 & 1.429 & 96.812 \\
20 & 0.056 & 1.175 & 97.987 \\
21 & 0.046 & 0.910 & 98.897 \\
22 & 0.035 & 0.548 & 99.445 \\
23 & 0.021 & 0.397 & 99.842 \\
24 & 0.015 & 0.158 & 100.00 \\
25 & 0.006 & &
\end{tabular}

Source; Computed from field survey, 2012.

Note: $Y_{1} \ldots . . Y_{25}$ are components generated for the variables plained is referred to as the efficient component and was therefore picked. The corresponding factor scores/eigen vector to the first principal component is the vector of weights for the explanatory variables and was used in equation (1) to calculate the asset index. 
Scoring factors, means and standard deviations from Principal Component analysis of 25 variables

The first principal component is the linear index of variables with the largest amount of information (variance) common to all of the variables. We consider only the first principal component due to a sharp decrease in proportion of explained variance (eigen values) in the components. The first principal component is then referred to as the efficient component. The corresponding eigen vectors (factor scores) to the first principal component is the vector of weights for the explanatory variables forming the first principal component.

The output from a principal component analysis is a table of factor scores (eigen vectors) or weights for each variable corresponding to each principal component. Generally, a variable with a positive factor score is associated with higher socio economic status and conversely, a variable with a negative factor score is associated with lower socio economic status (Luciano, 2006)

In this study, factor scores are positive for all asset variables specified and this shows that they all carry weight in determining the socio economic status of the rural households. Table 2 shows the scoring factors, means and standard deviations of all the 25 asset variables.

The interpretation of the scoring factors is quite straightforward; each of them is the specific contribution of the relative variable in determining household wealth. As the entire set of asset variables is dichotomous (zero or one) a move from zero to one changes the asset index by a factor score of each asset divided by its standard deviation.
This shows that since the variables are dummy variables, then fi/si gives the effect of a change from 0 to 1 on the household asset.

As revealed in the table 2, a household that owns land in the rural area has an asset index higher by 0.449 than another household without it and a household owning a motorcycle raises a household's asset index 0.431 higher than a household with no motorcycle. The asset variables having high contribution to the total household asset are education of the household head with a value of 0.453 , landed property in the rural area with a value of 0.449 , motorcycle with a value of 0.431 , radio with a value of 0.428 , video player and television with values of 0.427 and 0.418 respectively. Using the factor scores for all the asset variables from the first principal component as weights, the household asset index (household socio economic score) was calculated using the formula presented in equation 1.

The sum of all the asset indices for all the variables for each household was calculated as the household asset index. The already calculated household asset index was then used to categorize households into socio economic groups or categories. The household asset index for this study fell between the values -2.84 and 5.33 .

Source: Computed from field survey, 2012. Following the works of Filmer and Pritchett (2001); Seema et al .,2006) and Gwatkin et al., (2000) for this study, we sorted household asset index in descending order and classified the lowest $40 \%$ of the households as core poor group, the highest $20 \%$ as the non-poor or rich group and the middle $40 \%$ as the moderately poor group. Based on this classification, the mean household asset index for each group was calculated and the 
result is presented in Table 3.

Mean socio - economic asset score by poverty category.

The result in table 3 shows that the asset index approach in classifying households into different socio economic groups worked quite well as the households catego- rized as core poor were clearly delineated having a mean asset index of -1.67 from households categorized as moderately poor having a mean asset index of 0.09 and households categorized as non-poor with a mean asset index of 3.20.

Table 2; Scoring factors, mean and standard deviation from Principal Component Analysis of 25 asset variable

\begin{tabular}{lcccc}
\hline Variable & $\begin{array}{c}\text { Scoring } \\
\text { factor }\end{array}$ & Mean & $\begin{array}{c}\text { Standard } \\
\text { deviation }\end{array}$ & $\begin{array}{c}\text { Scoring factor/ } \\
\text { standard deviation. }\end{array}$ \\
\hline Own television & 0.203 & 0.6231 & 0.486 & 0.418 \\
Own video & 0.213 & 0.5462 & 0.499 & 0.427 \\
Own radio & 0.210 & 0.6000 & 0.491 & 0.428 \\
Own tape recorder & 0.127 & 0.2654 & 0.442 & 0.287 \\
Own refrigerator & 0.071 & 0.1962 & 0.398 & 0.178 \\
Own freezer & 0.009 & 0.0769 & 0.267 & 0.034 \\
Own furniture set & 0.093 & 0.1731 & 0.379 & 0.245 \\
Own car & 0.088 & 0.1769 & 0.382 & 0.230 \\
Own motorcycle & 0.195 & 0.2846 & 0.452 & 0.431 \\
Own grinding mill & 0.008 & 0.0962 & 0.295 & 0.027 \\
Own stove & 0.107 & 0.7385 & 0.440 & 0.243 \\
Own cooker & 0.014 & 0.0846 & 0.295 & 0.047 \\
Own land (rural area & 0.218 & 0.3692 & 0.486 & 0.449 \\
Own land (urban area) & 0.002 & 0.0308 & 0.173 & 0.065 \\
Own house (rural area) & 0.157 & 0.2654 & 0.442 & 0.355 \\
Own house (urban area) & 0.045 & 0.1154 & 0.320 & 0.140 \\
Type of roofing material & 0.000 & 0.990 & 0.088 & 0.00 \\
Type of exterior wall & 0.114 & 0.830 & 0.379 & 0.300 \\
Type of floor material & 0.091 & 0.860 & 0.346 & 0.263 \\
Type of electricity supply & 0.108 & 0.770 & 0.425 & 0.254 \\
Type of toilet & 0.053 & 0.150 & 0.354 & 0.150 \\
Source of water & 0.200 & 0.410 & 0.492 & 0.407 \\
Type of fuel & 0.201 & 0.450 & 0.499 & 0.403 \\
Education of household & 0.213 & 0.330 & 0.470 & 0.453 \\
head & & & & \\
Farmland & 0.003 & 0.042 & 0.202 & 0.015 \\
& & & &
\end{tabular}

Source: Computed from field survey, 2012.

Following the works of Filmer and Pritchett (2001); Seema et al.,(2006) and Gwatkin et al., 
Table 3: Mean socio economic score by poverty category.

\begin{tabular}{llll}
\hline & Core Poor & Moderately poor & Non poor \\
mean index & -1.67 & 0.09 & 3.20 \\
\hline
\end{tabular}

Source; Computed from field survey, 2012.

Estimated Ordered Probit model showing the correlates of poverty among the rural households.

Table 4 presents the result of the ordered probit model used to investigate the correlates of poverty among the rural households. The three categories of poverty namely core poor, moderately poor and non -poor groups formed the dependent variable as ordered 0,1 and 2 variables respectively while 9 explanatory variables were considered in the model. From the 9 explanatory variables included in the model, seven were statistically significant at various risk levels. They were age of household head, sex of household head, household size, primary occupation of household head, educational status of male household head and educational status of the wife. The likelihood ratio chi - square of 135.20 and a p value of 0.0000 reveal that the model as a whole is statistically significant. The dependent variable here is the poverty status. It is ordered and shows the economic status a household falls into namely the core poor, moderately poor and non poor households. The interpretation of the magnitude and signs of the coefficients is in line with the works of Bogale, (2011) and Budria, (2010). The marginal effects of the explanatory variables have been computed for the 3 categories of poverty which reflects the effect of a unit change in any explanatory variable on the probability of a household being core poor $(\mathrm{Y}=0)$, moderately poor $(\mathrm{Y}=1)$ and non poor $(Y=2)$. Table 5 shows the mar- ginal effects of the variables which allow further assessment of the estimate with respect to each poverty category. These marginal effect figures further strengthen the inferences obtained from the parameter estimates in the ordered probit model.

The age of household head is significant at $(p<0.01)$ and negatively related to the poverty status (economic status) of the household. This shows that younger household heads possess more assets than older ones. This may be especially true for older household heads who do not have reliable investments that could fetch them money at later age. The sex of the household head was also significant at $(p<0.05)$ and negatively related to the poverty status of the households and this reveals that an average female headed household was less likely to escape poverty. The primary occupation of the household head was significant at $(p<0.01)$ level though the coefficient has a negative sign indicating that the poverty status tend towards the poor category as the household head take up farming activities as their primary occupation. This shows that household heads who are farmers tend to fall into the core poor group. This result might be due to the fact that many of the farmers do not own a farmland, many of them use communal land for farming activities and this communal land cannot be sold or shared but members of the community are allowed to farm on them. Such farmlands cannot be used to plant permanent crops like cocoa, coffee, 
kola-nut, orange etc which can generate income to household even at old age. Other farmers rent the farm plots they use. The farmers in the study area are generally asset poor.

In terms of human capital, the educational status of male household head was significant at $(p<0.01)$ and the coefficient sign was positive. This shows that poverty status tend to fall into the non poor group as the educational status of the male household head increases, the male household heads having secondary school education and above tend to be non-poor. The educational status of wives was also significant at $(\mathrm{p}<0.05)$ with a positive sign and this also show that as the educational status of the woman in the household increases, households tend to be non poor. The share of wife's asset in value was not significant in this study and this shows that the female asset value does not influence household poverty in any way. This could be due to the fact that female asset ownership was small relative to what the men own in a household. Culturally, what a woman owns is under control and belongs to her husband. Conclusively, among other factors influencing poverty status in the rural household, the primary occupation of male household head has significant effect on the poverty status; farmers are more likely to be poor. This is due to the fact that many of the farmers lack productive assets. The above result therefore permits the rejection of the earlier stated null hypothesis that the primary occupation of male household heads has no significant effect on rural household poverty status.

Table 4: Estimated Ordered Probit model showing the correlates of poverty among the rural households.

\begin{tabular}{|c|c|c|c|}
\hline Explanatory variables & $\begin{array}{l}\text { Regression } \\
\text { parameters } \\
\text { Coefficient }\end{array}$ & Standard er- & $\mathrm{Z}$ - value \\
\hline Age of household head & $-0.0222^{* * *}$ & 0.007958 & -2.79 \\
\hline Sex of household head & $-0.7596 * *$ & 0.7174 & -1.06 \\
\hline Marital status of household head. & -0.0452 & 0.6936 & -0.07 \\
\hline Household size & $0.0699 *$ & 0.3719 & 1.88 \\
\hline Number of dependants & 0.0404 & 0.1888 & 0.21 \\
\hline $\begin{array}{l}\text { Primary occupation of household } \\
\text { head }\end{array}$ & $-0.629 * * *$ & 0.2006 & -3.14 \\
\hline Total female asset value & $3.03 e-08$ & $1.81 \mathrm{e}-07$ & 0.17 \\
\hline $\begin{array}{l}\text { Educational status of household } \\
\text { head }\end{array}$ & $0.6718^{* * *}$ & 0.17735 & -3.79 \\
\hline Educational status of mother & $0.4179 * *$ & 0.2099 & -1.99 \\
\hline
\end{tabular}

Source; Computed from field survey, 2012.

*** Significant at $1 \%$, ** Significant at $5 \%$ and $*$ Significant at $10 \%$

Number of Observations $=260 \quad \mathrm{R}^{2}=0.6465 \quad$ LR Chi $^{2}(10)=135.20$

Loglikelihood $=-206.68068 \quad$ Prob $>$ Chi $^{2}=0.0000$ 
Marginal probability effects on poverty status.

According to Spryskov, (2003), if a coefficient for a variable is statistically significant, this means that this variable influences the probability that a household is in one of the three poverty categories. Nevertheless, the marginal effects of a change in a variable on the probability of being in one group can be different from the marginal effect on the probability of being in other groups. Comparing the corresponding values and signs of the marginal effects, it is possible to understand the contribution of the variables on the probability of being in a certain poverty profile.

Table 5 shows the marginal probability effects of different covariates. The first line shows that households headed by older individuals are more prone to be in the core poor group of the poverty profile. Specifically, being one year older increases the probability of falling into the core poor group by 0.82 percent while it decreases the probability of being in the moderately poor and non poor groups by 0.37 and 0.45 percent respectively.

Table 5; Marginal probability effects on poverty status.

\begin{tabular}{llll}
\hline Variables & Core poor $(40 \%)$ & $\begin{array}{l}\text { Moderately poor } \\
(40 \%)\end{array}$ & Non poor $(20 \%)$ \\
\hline Age & $0.0082^{* * *}$ & $-0.0037^{* *}$ & $-0.0045^{* * *}$ \\
Sex & $0.2935^{* *}$ & $-0.1820^{* *}$ & $-0.00451^{* *}$ \\
Marital status & 0.0165 & -0.0072 & -0.00934 \\
Household size & $-0.0257^{*}$ & $0.0115^{*}$ & $-0.0142^{*}$ \\
Number of depend- & -0.0148 & 0.0067 & 0.0082 \\
ant & $0.2415^{* *}$ & $-0.1383^{* *}$ & $-0.1031^{* * *}$ \\
Primary occupation & $-0.2319^{* * *}$ & $0.0769^{* * *}$ & $0.1549^{* * *}$ \\
Father's education & $-0.1447^{* *}$ & $0.0474^{* *}$ & $0.0973^{*}$ \\
Mother's education & 1.12 & 0.501 & 0.615 \\
Share of wife's asset & 12 & &
\end{tabular}

$* * *$ Significant at $1 \%, * *$ Significant at $5 \%$ and $*$ Significant at $10 \%$.

Source; Computed from field survey, 2012.

Being a female headed household increases the probability of falling into the core poor group by 29.35 percent while it decreases the probability of being in the moderately poor and non poor groups by 18.20 and 0.45 percent respectively.

In terms of household size, a unit increase in the number of household members de- creases the probability of falling into the core poor and non poor groups by 2.57 percent and 1.42 percent respectively while increasing the probability of falling into the moderately poor group by 1.15 percent. This means that larger household sizes tend to be more in the moderately poor group. 
The marginal results for primary occupation of male household heads where the variable is a dummy with farming occupation being the primary occupation taking the value of 1 and non farming taking the value of zero, shows that a unit increase in the household head taking up farming as their primary occupation increases the probability of falling into the core poor group by 24 percent while it decreases the probability of falling into the moderately poor and non poor groups by 13.8 percent and 10 percent respectively. This means that household heads whose primary occupation is farming tend to fall into the core poor group.

In terms of human capital (education), a unit increase in the number of fathers with more than secondary school education decreases the probability of falling into the core poor group by 23.19 percent while increasing the probability of falling into the moderately poor and non poor groups by 7.69 percent and 15.49 percent respectively. Conclusively, more educated fathers tend to fall in the non poor groups. A $1 \%$ increase in the total household asset value decrease the probability of falling into the core poor group by 31 percent while it increases the probability of falling into the moderately poor group and non poor group by 59 percent and 72.4 percent respectively.

\section{CONCLUSION AND RECOMMENDATION}

The asset index approach in poverty analysis is robust and can be used as an alternative measure to assess household socio economic positions. The farmers in the study area are asset poor. The study therefore suggested that the economic situation of rural households can be considerably enhanced by promoting member's access to qualitative education and also by encourag- ing household heads who take up farming activities as their primary occupation to participate in credit associations, indigenous savings and micro financing so as to boost their farming. Therefore, rural development policies should be tailored towards developing these facilities.

\section{REFERENCES}

Ainsworth, M. and Filmer, D (2006). Children's Schooling: AIDS, Orphan hood, Poverty, and Gender. World Development 34 (6):1099-1128.

Awe, A. and Ojo, R (2012). Determinants of Income Distribution in the Nigerian Economy: 1977 - 2005. Journal of International Business and Management, Vol 5 (1) : 126 - 137. Baschieri, A and Craig, H (2004). Creating a Poverty Map for Azerbaijan , Programmatic Poverty Assessment 2004.

Bicego, G., Rutstein, S and Johnston K (2003). Dimensions of the Emerging Orphan Crisis in Sub-Saharan Africa. Social Science and Medicine 56(6):1235-1247.

Bogale, A (2011). Analysis of poverty and it's covariates among small holder farmers in Eastern Hararghe islands of Ethiopia. Journal of Development and Agricultural Economics Vol. 3 (4), pp.157- 164.

Bollen, K., Glanville, J. and Stecklov, G (2002). Economic Status Proxies in Studies of Fertility in Developing Countries; Does the Measure Matter? Population Studies, Vol 56; 81-96.

Budria, S (2010) The Socio- Economic Determinants of Economic Inequality, Evidence from Portugal. Revista Internacional de Sociologia (RIS) Vol 68 (1): pp 110-112. 
Case, A., Paxson, $\mathrm{C}$ and Ableidinger, J (2004). "Orphans in Africa: ParentalDeath, Poverty, and School Enrollment." Deography 41(3): 483-508.

Earth Trends (2003). Economic Indicators Nigeria.

Edoumiekumo, S., Karimo, M. and Tombofa, S (2014) Income Poverty in Nigeria: Incidence, Gap, severity and Correlates. American Journal of Humanities and Social Sciences, Vol 2 (1): 1- 9.

Evans, D. and Miguel, T (2004). Orphans and Schooling in Africa: A Longitudinal Analysis. Unpublished manuscript, Harvard University and University of California,Berkeley

Fay, M., Daniel L., Quentin W. and Tito Y (2005).Achieving Child- Health-Related Millennium Development Goals: The Role of Infrastructure. WorldDevelopment 33 (8):1267-1284.

Federal Office of Statistics (FOS), (1999) : Poverty Profile for Nigeria 19801996, FOS Lagos.

Filmer,.D. and Pritchett, L.Z. (1998). Estimating Wealth Effects without Income or Expenditure Data- or Tears; Educational Enrolment in India', World Bank Policy Research Working Paper, No 1994, Washington DC; World Bank ( also published in Demography (2001) Vol. 38, No 1).

Filmer, D, and Pritchett L (1999). The Effect of Household Wealth on Educational Attainment: Evidence from 35 Countries. Population and Development Review 25 (1) : 85 120.
Filmer, D and Pritchett, L (2001) Estimating Wealth effects without expenditure data or tears; an application to educational enrolments in India. Demography Vol. 38 (1).

Filmer, D (2005). Fever and Its Treatment Among the More and Less Poor in SubSaharan Africa. Health Policy and Planning 20 (6):337-346.

Filmer, D (2008). Disability, Poverty and Schooling in Developing Countries: Results from 14 Household Surveys. World Bank Economic Review.

Fitch Report, (2016). Evaluation Report on Economic Performance of some countries in Africa, Asia and the Middle East by Fitch International rating agency. Downloaded from www.thisdaylive.com/.

Ghuman, S, Behrman, J,B. Borja, Socorro Gultiano, and Elizabeth M. King (2005). Family Background, Service Providers, and Early Childhood Development in the Philippines: Proxies and Interactions." Economic Development and Cultural Change 54(1):129-164. Greene, W.H ( 2002) . Econometric Analysis. $5^{\text {th }}$ edition. Engelwood Cliffs, NJ: Prentice Hall.

Gwatkin, D. R., Shea R., Johnson, K. ,Pande, $R$ and Adam Wagstaff, (2000). Socio-Economic Differences in Health, Nutrition, and Population." HNP/ PovertyThematic Group, The World Bank, Washington, DC.

Handelman, H. 2016. Challenges of the Developing World. Eight Edition, Published by Rowman and Littlefield Publishing group, Inc boulevard, Suite 200, Lanham, Maryland, USA. 
Houweling, T.A.J, Kunst, A.E, Machenbach J.P.(2003). Measuring Health Inequality Among Children in Developing Countries; Does the Choice of the Indicator of Economic Status matter? International Journal for Equity in Health 2: 8.

Kpakol, M (2005). Major Challenges Facing Africa: Guardian Newspapers, April 4 pp. A2, A6.

Luciano, C.(2006). The Many Dimensions of Poverty in Albania : Income, Wealth and Perceptions. MPRA Paper No. 922. 9munich Personal RePEc Archive). http : // mpra.ub.uni-muenchen.de/922.

\section{National Bureau of Statistics (2012).}

Downloaded from

www.businessdayonline.com . Percentage of the Nigerian Population Living in absolute poverty.

National Bureau of Statistics (2016). Downloaded from www.vanguardnewsonline.com . Poverty: $112 \mathrm{~m}$ Nigerian live below poverty line.

Njau, J. D., Goodman, C., Kachur, S. P., Palmer, N.,R., Khatib, R.A., Abdulla, S., Mills, A. and P. Bloland. (2006). Fever Treatment and Household Wealth: The Challenge Posed for Rolling Out Combination Therapy for Malaria." Tropical Medicine \& InternationalHealth 11(3):299-313.

Ogwumike, F.O. (2002). Concept, Measurement and Nature of Poverty in Nigeria. Paper presented at the National PRSP Empowerment Workshop, Kaduna.

Olaniyan, O. (2000). Household Endowments and Poverty in Nigeria. A Paper presented at Centre for the Study of African
Economy Conference on Opportunities in Africa. University of Oxford,U.K.

Olowa, W (2012). Concept, Measurement and Causes of Poverty: Nigeria in Perspective. American Journal of Economics Vol 2 (1) : 25- 36.

Oshelowo,S. (2010). Galloping Poverty in Nigeria; An Appraisal of the Government's Interventionist Policies. Journal of Sustainable Development in Africa (volume 12 , No. 6, 2010)

Phusit, P (2003). An Application of Asset Index for Measuring Household Living Standards in Thailand. International Health Policy Program Thailand.

Povoroznyk, B (2006). Infrastructural Povery Conception and Welfare Estimation in Ukraine. A thesis submitted in partial fulfillment of the requirement for the degree of Masters of Arts in Economics. National University Kyiv- Mohyla Academy, Economics Education and Research Consortium, Ukraine.

Sahn, D. and Stifel D. (2000). Poverty Comparisons Over Time and Across Countries in Africa , World Development, Vol 28, No. 12 ; 2123- 55.

Sahn, D and Stifel, D. (2001). Exploring Alternative Measures of Welfare in the Absence of Expenditure Data. mimeo paper, Cornell University.

Sahn, D.and Stifel, D.C.(2003). Exploring Alternative Measures of Wealth in the Absence of Expenditure Data. The Review of Income and Wealth, 49 (4): 463-89

Sastry, N (2004). Trends in Socioeconomic Inequalities in Mortality in Developing Countries: The case of Child Survival in Sao 
Paulo, Brazil. Demography 41(3): 443-464..

Seema, V. and Lilani, K (2006). Constructing Socio - economic Status Indices; How to Use Principal Component Analysis. Published by Oxford University Press in Association with the London School of Hygiene and Tropical Medicine. Advance Access Publication 9.

Schellenberg, J. A., Cesar G. V., Adiel , M., Don de Savigny, David Schellenberg, Hassan M., and Bryce.J. (2003). Inequities Among the Very Poor: Health Care for Children in Rural Southern Tanzania." The Lancet 361(9357): 561- 566.

Spryskov,D.S,( 2003). Below the Poverty Line. Duration of poverty in Russia. Working paper No 03/04, Supported by the Economics Education and Research Consortium, Moscow; pp $1-79$.

Tarozzi, A. and Mahajan A. (2005). Child Nutrition in India in the Nineties: A Story of Increased Gender Inequality? Unpublished manuscript. Duke University and Stanford University. http://www.rand.org/ labor/pdfs/2006_tarozzi.pdf
United Nations Development Programme (UNDP), (2005). Human Development Report 2005. International Cooperation at Cross Roads : Aid, trade and Security in an Unequal world. New York : Oxford University Press for the United Nations Development Programme (UNDP).

United Nations Development Programme(UNDP) , (2016). Human Development Report 2016. UNDP ranks Nigeria 152nd in 2016 Human Development Index. Downloaded from https://dailytimes.ng/ news/undp-ranks-nigera-152nd-2016-human -development-index /

World Bank, (1996). Nigeria: Poverty in the Mist of Plenty: the Challenge of Growth with Inclusion. A World Bank poverty Assessment .Population and Human Resources division report 14733. Washington DC.

World Bank, (1997). Taking Action to Reduce Poverty in Sub Saharan Africa. (Development in Practice). A Poverty Report by World Bank. ISBN 10: 0821336983/ ISBN 13: 9780821336984 . Washington DC

(Manuscript received: 17th June, 2016; accepted: 13th February, 2016) 